\title{
Cohabitation of Ant Lions Palpares libelluloides (Linnaeus, 1764) and $P$. turcicus Koçak, 1976 (Neuroptera, Myrmeleontidae) in Azerbaijan
}

\author{
Ilhama Gudrat KERIMOVA ${ }^{1 *} \quad$ Nataly Yu. SNEGOVAYA ${ }^{2}$ \\ Viktor Anatolievich KRIVOKHATSKY3
}

${ }^{1,2}$ Institute of Zoology, National Academy of Sciences of Azerbaijan, A. Abbaszadeh str., 115, pr. 1128, bl. 504, Baku, Az1004, AZERBAIJAN

${ }^{3}$ Zoological Institute of the Russian Academy of Sciences, Universitetskaya Emb., 1, St.

Petersburg 199034, RUSSIA

e-mails: 1*ilkershah@mail.ru, ${ }^{2}$ snegovaya@yahoo.com, ${ }^{3}$ krivokhatsky@yandex.ru;

${ }^{3}$ myr@pochta.ru

ORCID IDs: ${ }^{1 *} 0000-0003-1946-6604,{ }^{2} 0000-0001-6060-6491,{ }^{3} 0000-0003-3362-3928$

\begin{abstract}
The overlapping distribution of two species of ant lions, Palpares libelluloides (Linnaeus, 1764) and $P$. turcicus Koçak, 1976, belonging to the P. libelluloides species group in Azerbaijan are examined. The peculiarities of their cohabitation in the Ordubad district are reported.
\end{abstract}

Key words: Habitat, censusing, landscape distribution, phenology.

Kerimova, I.G., Snegovaya, N.Y., \& Krivokhatsky, V.A. (2021). Cohabitation of ant lions Palpares libelluloides (Linnaeus, 1764) and P. turcicus Koçak, 1976 (Neuroptera, Myrmeleontidae) in Azerbaijan. Journal of the Entomological Research Society, 23(2), 179-186. 


\section{INTRODUCTION}

Two colorful, externally similar, species of ant lions (Figs. 1-4), were studied. Both belong to the Palpares libelluloides species group (Krivokhatsky et al, 2017) and are represented in Azerbaijan by the Holomediterranean (Palpares libelluloides (Linnaeus, 1764)) and Kura- Araksian-Anatolian (P. turcicus Koçak, 1976). Previously they were not found simultaneously in the same habitat, in sympatric zones, in the Caucasus and in Iran. In the Caucasus, Palpares libelluloides has been reported in Russia and in all Transcaucasian countries, including Turkey; P. turcicus is known only from Armenia, Azerbaijan, Russia, and Turkey; it was not recorded in Georgia (Krivokhatsky et al, 2017). In Iran Palpares libelluloides was registered in the provinces of Azarbayjan Sharghi Prov., Fars Prov., Kermanshah Prov., Lorestan Prov., Markazi Prov., Sistan and Baluchestan Prov., Tehran prov., Zanjan Prov. and W. Azarbayjan, and P. turcicus in Alborz Prov., Hamadan Prov., Kordestan Prov., Lorestan Prov., Markazi Prov., Tehran Prov., Zanjan Prov. and W. Azarbayjan.

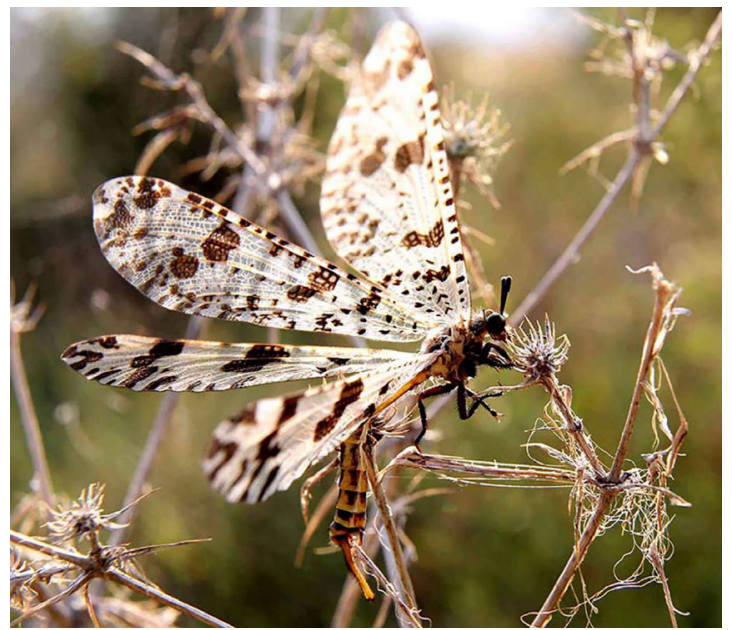

Fig. 1. Palpares libelluloides. Male in natural habitat (territory of the Agdara observatory in the Ordubad district. Nakhchivan. Azerbaijan. 2017) (Photo of I.G.Kerimova).

These and other pairs of species of the $P$. libelluloides group have only been reported to occur in isolation in sympatric zones according to the principle of landscape delimitation (Krivokhatsky et al, 2017; Kerimova \& Krivokhatsky, 2018), and even in the last publication we had not noted areas of cohabitation of $P$. libelluloides and $P$. turcicus.

The morphotypes and ecological niches of both species are similar. Both species belong to brightly colored, large-winged predatory, diurnal bimotor strong flyers of open spaces. Larvae of both species are predators and do not build a pit in the sand but lie in wait for their prey. The isolating mechanisms that prevent species from hybridizing are not clear; specimens described as hybrids have not been identified in the collections. Therefore, it was interesting to study the distribution of these two related species in the area of their close contact. 
Cohabitation of Ant Lions P. libelluloides and P. turcicus (Neuroptera, Myrmeleontidae)

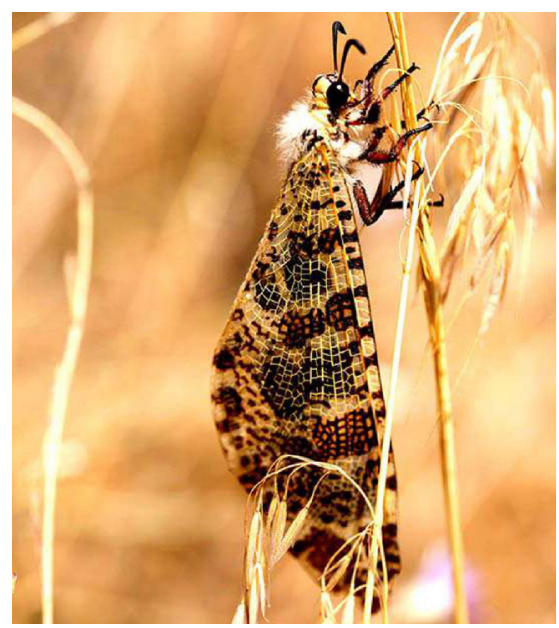

Fig. 2. Palpares turcicus. Female in natural habitat (territory of the Agdara observatory in the Ordubad district. Nakhchivan. Azerbaijan. 2018) (Photo of N.Yu.Snegovaya).

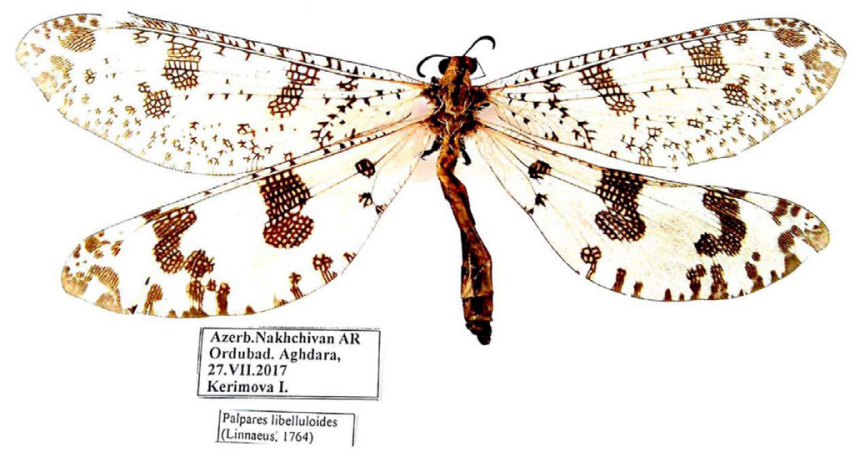

Fig. 3. Palpares libelluloides. Female (collection of the Institute of Zoology. National Academy of Sciences of Azerbaijan) (Photo of I.G.Kerimova).

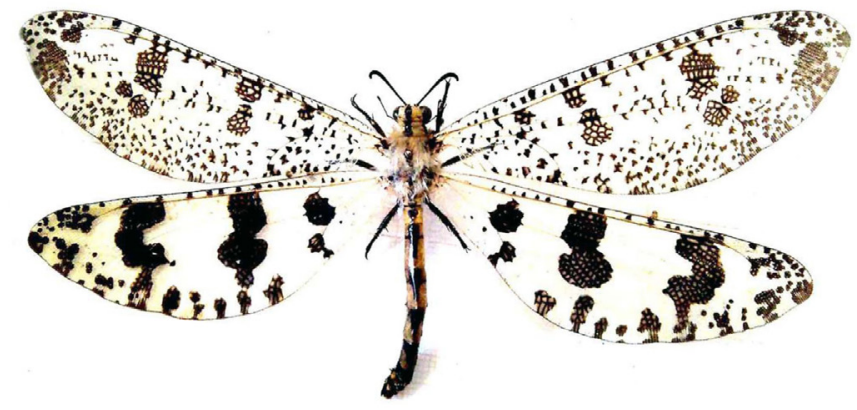

Fig. 4. Palpares turcicus. Female (Nakhchivan Azerbaijan. Ordubad. Agdara. 10.07.2018. (collection of the Institute of Zoology. National Academy of Sciences of Azerbaijan) (Photo of I.G.Kerimova). 
It seemed earlier that the places of these species are complementary in low-mountain semi-arid landscapes in such a way that $P$. libelluloides prefers flat plains at different elevations, while $P$. turcicus prefers mountain slopes. Recently, we found an area of overlapping places with two types of habitats, which allows us to look at this geographical phenomenon under a stronger, increased ecological view and to consider biotopes occupied by closely related species. We took into account the distribution of adults only, since the way of life of the larvae has not been established yet.

In the newly discovered areas of cohabitation [Ordubad district, between the village of Tivi and the Agdara observatory (Figs. 5-7)], adults of $P$. turcicus and $P$. libelluloides occur together sympatrically, practically throughout the entire period of simultaneous flight.

Further research is required to explain the reasons for this phenomenon, which has not been previously noted in other regions.

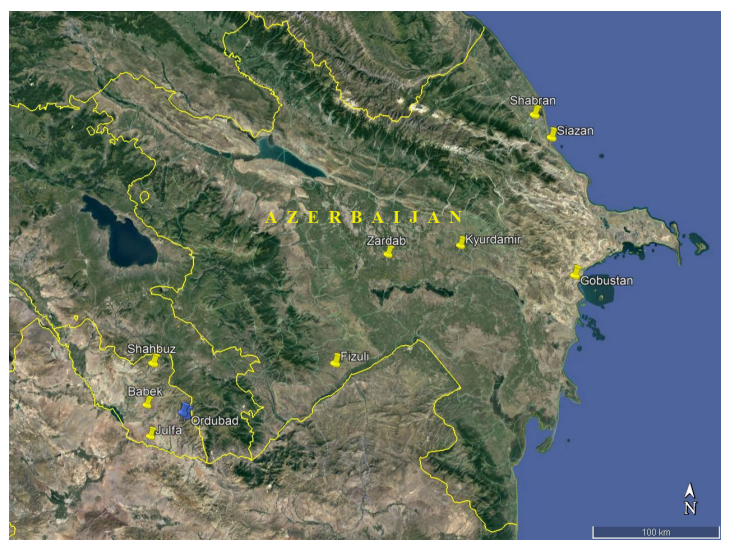

Fig. 5. Collection sites of ant lions of the genus Palpares Rambur in Azerbaijan. Yellow icons-locations of $P$. libelluloides; blue icon-co-habitating siteof $P$. libelluloides and $P$. turcicus.

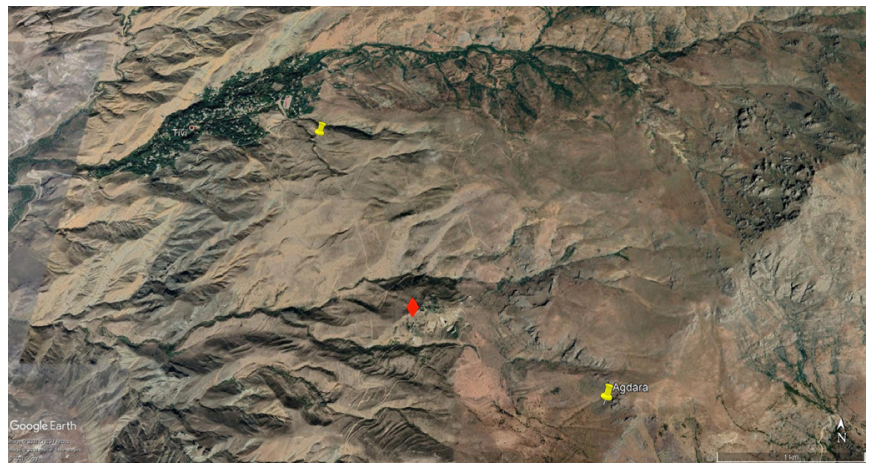

Fig. 6. Map of Tivi-Agdara sites in the area of co-habitation of $P$. libelluloides and $P$. turcicus. Red

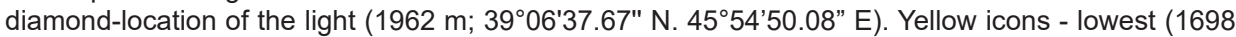

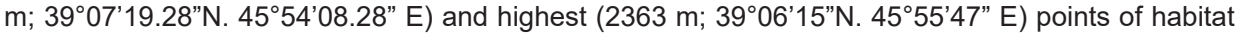
of $P$. turcicus. 


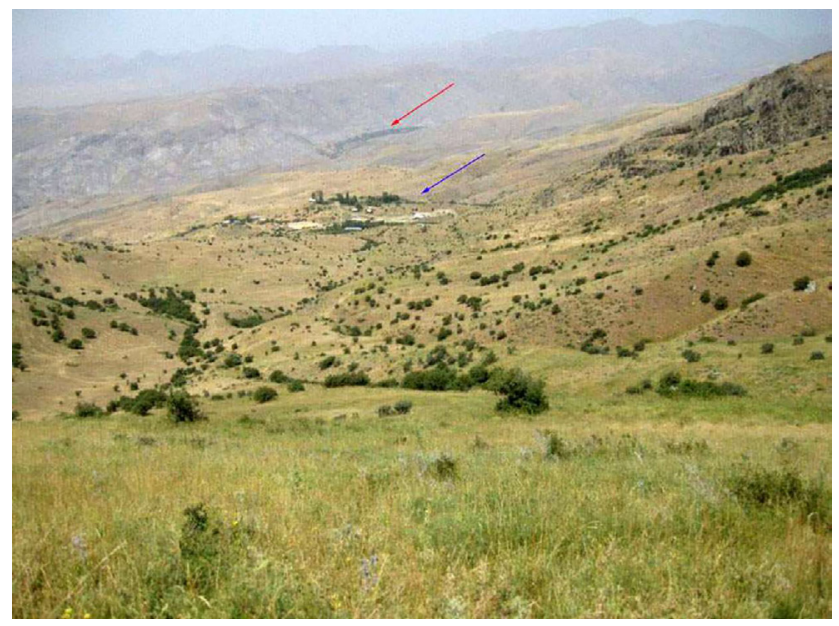

Fig. 7. Mid-mountain landscape example found near areas of Tivi-Agdara. Red arrow-Tivi. Blue arrowAgdara.

\section{MATERIAL AND METHODS}

The study was performed in and around the village of Tivi and the Agdara observatory of Ordubad district of the Nakhchivan Autonomous Republic. In total, more than 300 specimens of $P$. libelluloides (of which 66 were collected in the Nakhchivan Autonomous Republic, hereinafter -Nakhchivan) and 75 specimens of $P$. turcicus (all from Nakhchivan) were recorded from Azerbaijan (Table 1). There were 159 specimens of these species recorded in areas of cohabitation in the Ordubad district of Nakhchivan between the Village Tivi (site 1) and the Agdara observatory (site 2), i.e., in the altitude range from 1698 to $2363 \mathrm{~m}$. The collections of both species in Azerbaijan (Table 1, Fig. 5) were made from 2012 to 2019, and the censusing in the areas of cohabitation (Figs. 6, 7) - in 2017 and 2018 (Table 2). Adults were collected using an insect net or were picked by hand from a light source between 21 and 23 o'clock. The light source was installed in Agdara (3906'37.67" N, 4554'50.08" E,1962 m a.s.I.).

The first cohabitated area of $P$. turcicus and $P$. libelluloides was located near the Village Tivi at the foot of the Zangezur ridge at an elevation of $1698 \mathrm{~m}$ a.s.l. Coordinates of the site are: $39^{\circ} 07^{\prime} 19.28^{\prime \prime} \mathrm{N}, 45^{\circ} 54^{\prime} 08.28^{\prime \prime} \mathrm{E}$. The vegetation cover is formed by mountain xerophytic, mainly perennial plant species, as well as umbellate and cruciferous, which often reach a height of $1-1.5 \mathrm{~m}$ in early summer.

The second cohabitated site of both species was located in Agdara at a distance of about $10 \mathrm{~km}$ from the Village Tivi; the maximum elevation of the second site, where ant lions were encountered was $2363 \mathrm{~m}$ a.s.l. The coordinates of the site are $39^{\circ} 06^{\prime} 37.67^{\prime \prime}$ $\mathrm{N}, 45^{\circ} 54^{\prime} 50.08$ " E. The plant associations of this site are mainly represented by different species of Acantholimon Boiss., Astragalus L. and Thymus L., as well as perennial 
KERIMOVA, I.G., SNEGOVAYA, N.Y., \& KRIVOKHATSKY, V.A.

herbaceous plants, legumes and Compositae which continue to bloom at the end of July. Dominant shrubs are represented by Crataegus Tourn. ex L. at an elevation of about $2000 \mathrm{~m}$ to the maximum for this site $2363 \mathrm{~m}$ above sea level, meadow-shrub and meadow-steppe vegetation is replaced by fescue steppes, fescue shrub steppes and tragacanths formed by thorny-shrub astragals (Ibrahimov, Nabiyeva, \& Salayeva, 2017). Both of these sites are used by the locals as pasture for sheep and goats.

Table 1. Localities of ant lions of the genus Palpares in Azerbaijan.

\begin{tabular}{|c|c|c|c|c|c|}
\hline \multirow{2}{*}{\multicolumn{2}{|c|}{ Collection sites, districts }} & \multirow{3}{*}{$\begin{array}{r}\text { Elevation }(\mathrm{m}) \\
424\end{array}$} & \multirow{3}{*}{$\begin{array}{l}\text { Coordinates } \\
\text { 46.61". E } 49^{\circ} 00^{\prime} 36.21\end{array}$} & \multicolumn{2}{|c|}{ Species } \\
\hline & & & & \multirow{2}{*}{$\begin{array}{c}\begin{array}{c}\text { Palpares } \\
\text { libelluloides }\end{array} \\
+\end{array}$} & \multirow{2}{*}{$\begin{array}{l}\text { Palpares } \\
\text { turcicus }\end{array}$} \\
\hline & & & & & \\
\hline & & 434 & N 41 ${ }^{\circ} 03^{\prime} 48.37^{\prime \prime}$. E 49 02'26.36" & + & \\
\hline \multirow[t]{4}{*}{ Siazan } & & -27.12 & N 405'ㄷ⒈82". E 49¹5'3.60" & + & \\
\hline & & 517.86 & N41 ${ }^{\circ} 03^{\prime 2} 23.50^{\prime \prime}$. E 4903'09.95" & + & \\
\hline & & -14.02 & N 405'ㄷ․62". E 49¹4'39.92 & + & \\
\hline & & 157 & N 4115'38.04". E 4852’55.65" & + & \\
\hline \multicolumn{2}{|l|}{ Shabran } & -25.82 & N 41ํ1'27.07". E 4904'51.68" & + & \\
\hline & & 625 & N 41ㅇ5'27.77". E 4856'30.04" & + & \\
\hline \multicolumn{2}{|l|}{ Gobustan } & 4.88 & N 4006'06.85". E 49²3'20.92" & + & \\
\hline Fizuli & & 152 & N 39²6'15.25". E 47²0'08.14" & + & \\
\hline \multirow{2}{*}{ Ordubad } & Agdara & 2363 & N $39^{\circ} 06^{\prime} 15^{\prime \prime}$. E $45^{\circ} 55^{\prime} 47^{\prime \prime}$ & + & + \\
\hline & Tivi & 1698 & N 3907'19.28". E 4554'08.28” & + & + \\
\hline \multicolumn{2}{|l|}{ Shahbuz } & 1727.61 & N 39²4'23.09”. E 4541'00.96" & + & \\
\hline Julfa & & 717.19 & 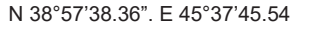 & + & \\
\hline Babek & & 1066 & N 39॰10'16.57". E 45³5'21.69" & + & \\
\hline \multicolumn{2}{|l|}{ Kyurdamir } & 70 & N $40^{\circ} 17^{\prime} 44.02^{\prime \prime}$. E 4820'17.62” & + & \\
\hline Zardab & & -5 & N 4013'50.12". E 47²4'13.03" & + & \\
\hline
\end{tabular}

Table 2. Number of specimens of Palpares libelluloides and P. turcicus in the area of their cohabitation.

\begin{tabular}{|l|c|c|c|c|}
\hline \multirow{2}{*}{ Sampling places } & \multicolumn{2}{|c|}{2018} & \multicolumn{2}{c|}{2019} \\
\cline { 2 - 5 } & \multicolumn{2}{|c|}{ Species } & \multicolumn{2}{c|}{ Species } \\
\cline { 2 - 5 } & Palpares libelluloides & $\begin{array}{c}\text { Palpares } \\
\text { turcicus }\end{array}$ & $\begin{array}{c}\text { Palpares libellu- } \\
\text { loides }\end{array}$ & Palpares turcicus \\
\hline Tivi & 20 & 10 & 10 & 15 \\
\hline Agdara & 60 & 30 & 25 & 35 \\
\hline
\end{tabular}

In Nakhchivan, the censusing and collection of material were carried out on mid-mountain meadows and on rocky gentle slopes along the Tivi-Agdara route (Figs. 6,7 ) at an elevation of 1698 to $2363 \mathrm{~m}$ a.s.I. In early July (from $1^{\text {st }}$ through $10^{\text {th }}$ ), only $P$. 
Cohabitation of Ant Lions P. libelluloides and P. turcicus (Neuroptera, Myrmeleontidae)

turcicus was recorded at the study site. The second species, $P$. libelluloides, does not appear until close to the end of July. A joint flight of both species was observed from 26 July to 3 August in 2018.

\section{RESULT AND DISCUSSION}

According to available data (Kerimova \& Krivokhatsky, 2018) P. libelluloides is widespread in Azerbaijan, and inhabits plains at different elevations from the western coast of the Caspian Sea (height-14 m a.s.l., 2017) to the mountainous regions of Nakhchivan (elevation $2363 \mathrm{~m}$ above sea level). P. libelluloides is characterized by yellow abdomen with brown longitudinal lines. In contrast to $P$. libelluloides, basal macula in the hind wing of $P$. turcicus has a circular form and covers both sectoral and cubital forks (Krivokhatsky et al, 2017). Palpares turcicus was recorded by us only in the Ordubad district (village Tivi, Agdara observatory) of Nakhchivan (Figs. 5, 6), where it forms part of the Kura-Araks population, which is well known from collections made in Armenia, Azerbaijan, and Turkey (Krivokhatsky et al, 2017). Here it lives on steep and gentle treeless slopes and has never been recorded by us on the plains far from the mountains.

Flights of $P$. libelluloides in other regions of Azerbaijan begin at the end of June and last until the last two weeks in August. In Agdara, we registered the beginning of the flight period of this species in the second half of July and it continues until the beginning of August. Flights of $P$. turcicus begin in early July and continue until early August. The period of maximum abundance of adults of both species co-occurs in July (Fig. 8).

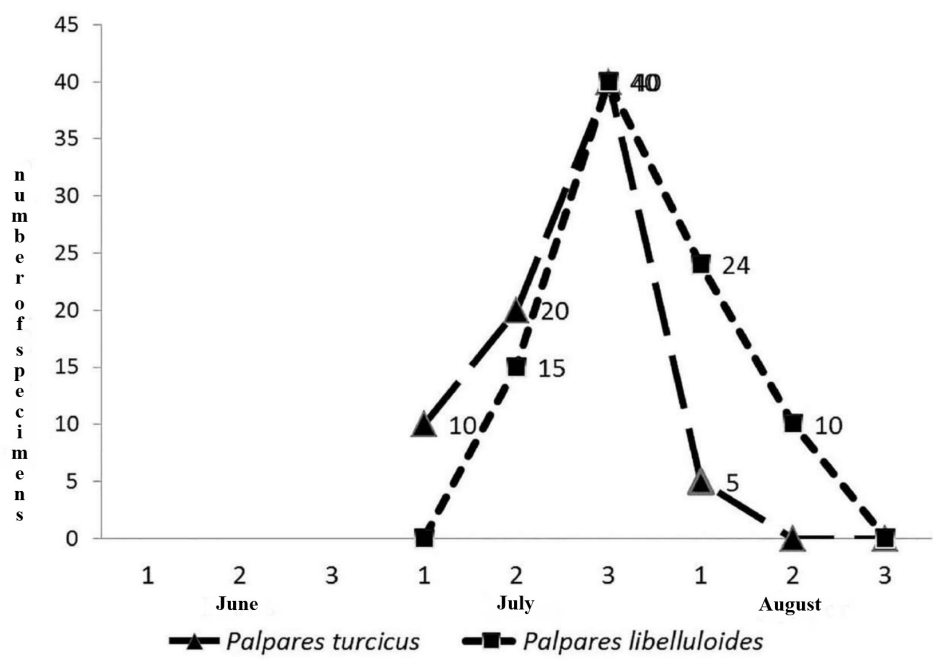

Fig. 8. Seasonal dynamics of the activity of $P$. turcicus and $P$. libelluloides in the area of cohabitation (TiviAgdara) according to the survey data on the routes in 2017 and 2018.

At the beginning of July, $P$. turcicus was recorded only on the survey route in Nakhchivan, with a counting density of 1-2 individuals per 10 meters of the route. Females of this species appeared here earlier than males and before the appearance of 
$P$. libelluloides at the end of July, after which both species were found in the same areas with the same density (1-2 specimens of $P$. libelluloides or 1-2 specimens of $P$. turcicus).

During the adult stage, both species coexist in low-mountain landscapes, inhabiting both slopes and valley areas.

The sex ratio for the entire collection period in both species ( $P$. libelluloides: $45 \mathrm{m \# ,} 50$ f\#; P. turcicus: $46 \mathrm{m \# ,} 65 \mathrm{f \# )} \mathrm{shows} \mathrm{a} \mathrm{slight} \mathrm{predominance} \mathrm{of} \mathrm{females} \mathrm{in} \mathrm{the} \mathrm{populations.}$

Thus, two species of the same genus were found together in areas studied by us in the Transcaucasia. Palpares libelluloides predominantly inhabited the lowlands and $P$. turcicus, predominantly inhabited the mid-mountain area. Simultaneous flight of stable populations of both species was recorded on slope biotopes for the three years they were observed.

\section{ACKNOWLEDGEMENT}

Data collection and preliminary analysis were partly carried out within the framework of the state subject ZIN No. AAAA-A19-119020690082-8.

The authors are grateful to Dr. A. P. Rasnitsyn (Moscow, Russia) and Dr. J.C. Cokendolpher (Lubbock, Texas, USA) for many useful comments that have improved the work.

\section{REFERENCES}

Ibrahimov, A.Sh., Nabiyeva, F.Kh., \& Salayeva, Z.K. (2017). Gornostepnaya rastitelnost Nakhchivanskoy Avtonomnoy Respubliki Azerbaidzhana. -- Innovcatsii v nauke: nauchniy zhurnal, Novosibirsk: ANS «SibAK», 5(66), 9-13.

Kerimova, I.G. \& Krivokhatsky, V.A. (2018). Current composition of the fauna of antlions (Neuroptera: Myrmeleontidae) of Azerbaijan. Caucasian Entomological Bulletin, 14(1),55-66. doi: 10.23885/18143326-2018-14-1

Krivokhatsky, V., Hajiesmailian, A., Mirmoayedi, A., Khabiev, G., Dobosz, R., \& Ostroverkhova, M. (2017). Palpares turcicus Koçak, 1976 - new name for Iranian fauna and its place in the $P$. libelluloides species group (Neuroptera: Myrmeleontidae). Proceedings of the Zoological Institute, 321(4),377-402. 